\title{
An initial survey of 150 horses from Thailand for anti-Pythium insidiosum antibodies
}

\section{Zin Mar Htun}

Department of Microbiology, Faculty of Medicine, Siriraj Hospital, Mahidol University, Bangkok, Thailand

\section{Aree Laikul}

Department of Large Animal and Wildlife Clinical Sciences, Faculty of Veterinary Medicine, Kasetsart University, Nakhon Pathom, Thailand

\section{Watcharapol Pathomsakulwong}

Equine Clinic, Kasetsart University Veterinary Teaching Hospital, Nakhon Pathom, Thailand

\section{Chompoonek Yurayart}

Department of Microbiology and Immunology, Faculty of Veterinary Medicine, Kasetsart University, Bangkok, Thailand

\section{Tassanee Lohnoo}

Research Center, Faculty of Medicine, Ramathibodi Hospital, Mahidol University, Bangkok, Thailand

\section{Wanta Yingyong}

Research Center, Faculty of Medicine, Ramathibodi Hospital, Mahidol University, Bangkok, Thailand

\section{Yothin Kumsang}

Research Center, Faculty of Medicine, Ramathibodi Hospital, Mahidol University, Bangkok, Thailand

\section{Penpan Payattikul}

Research Center, Faculty of Medicine, Ramathibodi Hospital, Mahidol University, Bangkok, Thailand

\section{Pattarana Sae-Chew}

Research Center, Faculty of Medicine, Ramathibodi Hospital, Mahidol University, Bangkok, Thailand

\section{Thidarat Rujirawat}

Research Center, Faculty of Medicine, Ramathibodi Hospital, Mahidol University, Bangkok, Thailand

\section{Chalisa Jaturapaktrarak}

Research Center, Faculty of Medicine, Ramathibodi Hospital, Mahidol University, Bangkok, Thailand

\section{Piriyaporn Chongtrakool}

Department of Microbiology, Faculty of Medicine, Siriraj Hospital, Mahidol University, Bangkok, Thailand

Theerapong Krajaejun ( $\nabla$ mr_en@hotmail.com )

Department of Pathology, Faculty of Medicine, Ramathibodi Hospital, Mahidol University, Bangkok, Thailand https://orcid.org/0000-0003-0545-3765

\section{Research Article}


Keywords: Pythiosis, Pythium insidiosum, seroprevalence, horse, Thailand

Posted Date: May 20th, 2020

DOI: https://doi.org/10.21203/rs.3.rs-29511/v1

License: (c) (1) This work is licensed under a Creative Commons Attribution 4.0 International License. Read Full License

Version of Record: A version of this preprint was published at Journal of Medical Mycology on March 1st, 2021. See the published version at https://doi.org/10.1016/j.mycmed.2020.101085. 


\section{Abstract}

Objectives: Pythium insidiosum causes a deadly condition, called pythiosis, in humans and other animals. The organism has been identified in tropical and subtropical environments worldwide. Since 1985 , human pythiosis has been increasingly reported from Thailand. Seroprevalence studies estimated that $\sim 32,000$ Thai people have been exposed to the pathogen. In 2018, the first animal pythiosis case in Thailand was diagnosed in a horse. In this study, we surveyed anti-P. insidiosum antibodies in a sample of the Thai equine population.

Results: Serum samples were available from 150 out of 6,353 registered horses distributed across Thailand. ELISA detected the anti-P. insidiosum antibodies in three horses. Immunochromatography and Western blot confirmed the presence of the antibodies in one of the ELISA-positive horses. Based on one positive out of 150 tested, the Pythium seroprevalence in the Thai equine population was $0.7 \%$, which is 10 times higher than that of the Thai human population. The seroprevalence of the anti-P. insidiosum antibodies in a small sample of horses suggests a higher incidence of pythiosis in horses than in humans. Larger studies will be necessary to obtain the full picture of the epidemiology of animal pythiosis in Thailand.

\section{Introduction}

Pythium insidiosum is capable of infecting humans, horses and dogs residing in tropical and subtropical areas across the globe [1,2]. The pathogen has been identified in water and soil samples from around the world [3-7]. Direct contact with P. insidiosum can initiate the deadly condition called pythiosis [1, 2, 810]. Laboratory tests are required to make a definitive diagnosis of pythiosis [1, 10-12]. Early and proper treatment may substantially improve the clinical outcomes for pythiosis patients $[1,2,10]$.

Data on the epidemiology of pythiosis is limited. Since the first case in 1985, human pythiosis has been increasingly reported from all over Thailand $[2,10,13-19]$, where $P$. insidiosum is ubiquitous in the environment [3, 4]. A seroprevalence study estimated that $~ 32,000$ Thai people have been exposed to the pathogen [20]. In the other endemic countries (i.e., Brazil, Costa Rica, the United States, and Australia), human pythiosis is relatively rare, whereas the disease in animals (i.e., horses and dogs) is much more prevalent $[1,21]$. It is unknown if it is host, pathogen, or environmental factors that contribute to the different prevalence of human and animal pythiosis.

Animal pythiosis was reported in Thailand in a horse in 2018 [22] and a dog in 2020 [23]. The relative paucity of reports of animal pythiosis in Thailand may result from under-recognition and under-diagnosis of the disease. To acquire evidence on the exposure of animals to the pathogen, we surveyed serum anti$P$. insidiosum antibodies in 150 horses distributed across Thailand, using 3 established serological tests: a protein A/G-based enzyme-linked immunosorbent assay (ELISA); a protein A/G-based immunochromatographic test (ICT); and Western blot analysis $[11,12,20]$. This study is a first step leading to a better understanding of the epidemiology of animal pythiosis in Thailand. 


\section{Materials And Methods}

Serum samples from 150 healthy horses were made available from the Faculty of Veterinary Medicine, Kasetsart University, Thailand (Table 1). The horses resided in northern $(n=43)$, central $(n=86)$, eastern $(n=14)$, and southern $(n=7)$ regions of Thailand. Serum samples from a Thai horse with culture-proven pythiosis and a healthy blood donor served as the positive and negative controls, respectively. The serum sample were tested (in duplicate) to detect the anti-P. insidiosum antibodies using an established protein A/G-based ELISA [11] with some modifications. Briefly, a 96-well polystyrene plate (Corning) was coated with $100 \mu \mathrm{l}$ of $5 \mu \mathrm{g} / \mathrm{ml}$ culture filtrate antigen (prepared from the human-isolated $P$. insidiosum strain Pi-S [24]) in $0.1 \mathrm{M}$ carbonate buffer ( $\mathrm{pH} 9.6)$ and $1.5 \% \mathrm{NaCl}\left(4{ }^{\circ} \mathrm{C}\right.$ overnight), washed 4 times with PBS and $0.05 \%$ tween-20 (PBS-T), blocked with $250 \mu \mathrm{l}$ of $0.5 \%$ bovine serum albumin (Merck) in PBS $\left(37^{\circ} \mathrm{C}\right.$ for 80 min), and washed 4 times again with PBS-T. A diluted serum sample (1:1,600 in PBS; $100 \mu \mathrm{l})$ was incubated in each well $\left(37^{\circ} \mathrm{C}\right.$ for $\left.1 \mathrm{hr}\right)$ and was washed 4 times with PBS-T. The peroxidase-conjugated protein A/G (Bio-Rad) $(1: 100,000$ in PBS; $100 \mu \mathrm{l})$ was added to each well and incubated at $37^{\circ} \mathrm{C}$ for $1 \mathrm{hr}$. After a washing step as above, the chromogenic substrate (Tetramethylbenzidine and $\mathrm{H}_{2} \mathrm{O}_{2} ; 100 \mu \mathrm{l}$ ) (Thermo Scientific) was added into each well and incubated in the dark at room temperature for 3 min. The enzymatic reaction was stopped by applying $100 \mu \mathrm{l}$ of $0.5 \mathrm{~N} \mathrm{H}_{2} \mathrm{SO}_{4}$. The optical density (OD) of every serum sample was measured (at 450-nm) by an Infinite 200 Pro microplate reader (Tecan). The obtained OD minus the blank OD (PBS) was divided by that of the negative control to provide an ELISA value (EV). The ELISA ${ }^{+}$cutoff point was determined to be the mean EV of all tested serum samples plus 3 SDs, as previously described by other investigators [12, 20,25].

All ELISA-positive sera, together with an equivalent number of randomly-selected ELISA-negative samples, were tested for the presence of anti-P. insidiosum antibodies by ICT [12] and Western blot analysis [20]. The positive and negative control sera were tested in parallel. A protein A/G-based ICT strip was dipped in $100 \mathrm{ul}$ of each serum sample, diluted 1:5,000 in $0.15 \mathrm{M} \mathrm{PBS}$ (pH 7.4), for $30 \mathrm{~min}$. The appearance of both test and control lines indicated an ICT-positive result, while the presence of only the control line indicated an ICT-negative result. For Western blot analysis, CFA of $P$. insidiosum [24] was separated by SDS-PAGE (4\% stacking and $12 \%$ resolving gels) using a Bio-Rad MiniProteon II apparatus (setting: $100 \mathrm{v}$ for $90 \mathrm{~min}$ ) and blotted onto anitrocellulose membrane (Bio-Rad) using a Bio-Rad Mini Trans-Blot apparatus (setting: $100 \mathrm{v}$ for $60 \mathrm{~min})$. The blotted membrane was blocked with $5 \%$ skimmed milk in PBS with $0.1 \%$ Tween20 (PBS-T) at room temperature for $60 \mathrm{~min}$, and incubated with a serum sample, diluted 1:2,000 in 1\% skimmed milk in PBS-T, at room temperature for $3 \mathrm{hr}$. After a washing step, the A/G protein, conjugated with horseradish peroxidase, wasadded to the membrane and incubated at room temperature for $2 \mathrm{hr}$. Western blot signals were generated using $0.03 \%$ diaminobenzidinetetrahydrochloride, $0.05 \%$ cobalt chloride, and $0.06 \%$ hydrogen peroxide in PBS.

The provinces where the equine serum samples were obtained were plotted on an on-line Thailand map using the Microreact software [26]. The most recent numbers of registered horses and farms were derived from the Department of Livestock Development, Ministry of Agriculture and Cooperatives, Thailand 
(http://en.dld.go.th/). Means, standard deviations (SD), and distribution histogram of EVs from all equine serum samples were obtained by using the EXCEL program (version 16.35).

\section{Results}

Serum samples were obtained from 150 horses (on 27farms) distributed in 8 provinces across Thailand (Table 1).. The geographic locations of these provinces (i.e., Chiang Rai, Payao, Suphanburi, Kanchanaburi, Ratchaburi, Chachoengsao, Chonburi, and Trang) is plotted on a map (Figure 1), which can be accessed online at https://microreact.org/project/f2QcmQktR. All serum samples (identifier [IDs]: \#1-150) were screened for anti-P. insidiosum antibodies by protein A/G-based ELISA [11]. With the "mean+3SDs" ELISA cut-off point (EV = 40.7), sera from 3 horses in Suphanburi (ID \#10; EV = 47.0), Kanchanaburi (ID \#98; EV = 60.9), and Trang (ID \#132; EV = 86.1) provinces tested positive, while that from the other 147 horses (average EV = 8.2; range: 1.3-33.5) were negative (Figure 2A)..

Three ELISA-positive sera (IDs \#10, 98, and 132), 3 randomly-selected ELISA-negative sera (IDs \#4, 19, and 77), and the positive and negative control sera were further analyzed using ICT and Western blot. The ICT test confirmed antibodies in the positive control and in one of the ELISA-positivesamples (ID \#132; Figure 2B).. Likewise, for the Western blot analyses, only the serum ID \#132 sample showed 7 prominent immunoreactive bands (i.e., 12, 18, 22, 27, 40, 55, $120 \mathrm{kDa}$ ) comparable with the reference bands of the positive control serum (from a culture-proven horse with pythiosis) (Figure 2C).. In contrast, the other 2 ELISA-positive sera, which had lower values in the ELISA test (IDs \#10 and 98), the ELISA-negative sera (IDs \#4, 19, and 77), and the negative control serum all resulted in only a few faint immunoreactive bands (i.e., 32, 40, and $120 \mathrm{kDa}$ ) (Figure $2 C$ )..

The presence of anti-P. insidiosum antibodies was detected in one out of 150 horses $(0.7 \%)$ by all 3 serological tests (i.e., ELISA, ICT, and Western blot). A total of 6,353 horses were registered in Thailand, according to the 2014 report of the Department of Livestock Development, Thai Ministry of Agriculture and Cooperatives (http://en.dld.go.th/). Based on our sample, the number of horses with a detectable level of anti-P. insidiosum antibodies is estimated to be 6.7 in 1,000 or 42 in the registered equine population in Thailand.

\section{Discussion}

Two seroprevalence studies of anti-P. insidiosum antibodies were independently conducted by Weiblen et al. in Brazil [25] and Lohnoo et al. in Thailand [20]. Weiblen et al. tested the sera from 1,002 out of $\sim 550,000$ horses in the Rio Grande do Sul State of Brazil and reported the seroprevalence of $11.1 \%$ [25, 27]. Lohnoo et al. assessed the sera from 2,641 people and estimated the seroprevalence of $0.07 \%$ (or 32,000 in the entire Thai human population) [20]. In the current study, serum samples were obtained from 150 out of 6,353 horses registered in Thailand (Table 1, Figure 1).. Based on the consensus results from 3 established serological tests (Figure 2), the seroprevalence of anti-P. insidiosum antibodies in 150 horses was $0.7 \%$ (or an estimated 42 in the entire Thai equine population). Such seroprevalence in Thai horses 
(0.7\%) is 10 times higher than that estimated for Thai people (0.07\%) [20] and 17 times lower than that of Brazilian horses (11.1\%) [25]. A higher seroprevalence implies a higher exposure rate of a target population to $P$. insidiosum.

Lower seroprevalence (0.7 vs. $11.1 \%$ ) and fewer horses than in the Rio Grande do Sul State of Brazil $(6,353$ vs. 550,000$)[25,27]$ explain why the number of horses with pythiosis in Thailand is minimal with just one case reported to date [28] vs. hundreds of Brazilian horses reported with the disease [29-36]. The striking difference in seroprevalences of the Thai $(0.7 \%)$ and Brazilian $(11.1 \%)$ horses could imply that Thai people, by comparison, might have a lower chance of having environmental exposure to $P$. insidiosum. However, the reported cases of human pythiosis from Thailand are much higher than those from Brazil [10,13,13,16,16,37-39]. A host or pathogen factors might contribute to such a different prevalence of human pythiosis: Thalassemia is a common underlying condition in Thai patients with pythiosis [2, 40]; Genotypes of the Thai $P$. insidiosum strains are different from that of the Brazilian strains $[41,42]$.

\section{Conclusion}

We report an initial survey of anti-P. insidiosum antibodies in 150 horses from Thailand, using 3 established serological methods (i.e., ELISA, ICT, and Western blot). The seroprevalence of the antibodies in the Thai equine population ( $0.7 \%)$ was markedly higher than that of the Thai human population $(0.07 \%)$, but much lower than that of the Brazilian equine population $(11.1 \%)$. The antibody surveillances reported by our group and other investigators were undertaken to promote a better understanding of the epidemiology and host susceptibility of pythiosis in different geographic locations. Larger studies will be necessary to obtain a complete picture of the epidemiology of pythiosis.

\section{Limitations}

Serum samples, used in this study, were derived from a limited number of horses (i.e., 150 out of 6,353 horses). Besides, the recruited horses were disproportionally distributed throughout Thailand. Therefore, the resulting seroprevalence is statistically limited.

\section{Abbreviations}

CFA Culture filtrate antigen

ELISA Enzyme-linked immunosorbent assay

EV ELISA value

ICT Immunochromatographic test

ID Identifier 
PBS Phosphate-buffered saline

PBS-T Phosphate-buffered saline and 0.05\% tween-20

SD Standard deviation

\section{Declarations}

\section{Ethics approval and consent to participate}

This study and the use of serum samples were approved by the Institutional Animal Care and Use Committee, Kasetsart University, Bangkok, Thailand (assigned number: ACKU61-VET-093), and the Committee for Research, Faculty of Medicine, Ramathibodi Hospital, Mahidol University, Bangkok, Thailand (assigned number: MURA2020/547).

\section{Availability of data and material}

The $P$. insidiosum strain Pi-S used for crude protein preparation is available upon request.

\section{Funding}

The authors acknowledge the financial support provided by Microbiology Department, Faculty of Medicine, Siriraj Hospital, Mahidol University [a Doctoral Student Competency Scholarship (Zin Mar Htun)]; Faculty of Veterinary Medicine, Kasetsart University [Cooperative Social Responsibility Program of Veterinary Practice-2018 (Chompoonek Yurayart)]; Thailand Research Fund [Grant numbers: RSA6280092 (Theerapong Krajaejun)]; and Faculty of Medicine, Ramathibodi Hospital, Mahidol University [Grant number: CF_61007 (Theerapong Krajaejun)].

\section{Acknowledgements}

We thank Thomas D. Sullivan for reviewing the manuscript.

\section{Consent for publication}

Not applicable.

\section{Competing interests}

None.

\section{Author's contributions}

Study design (ZMH, AL, PC, TK); Experiment \& Methodology (ZMH, AL, WP, CY, TL, WY, YK, PP, PS, TR, CJ, TK); Data collection (ZMH, AL, WP, CY, TL, TR, CJ, TK); Data analysis (ZMH, AL, WP, CY, PC, TK); 


\section{References}

1. Gaastra W, Lipman LJA, De Cock AWAM, Exel TK, Pegge RBG, Scheurwater J, et al. Pythium insidiosum: an overview. Vet Microbiol. 2010;146:1-16.

2. Krajaejun T, Sathapatayavongs B, Pracharktam R, Nitiyanant P, Leelachaikul P, Wanachiwanawin W, et al. Clinical and epidemiological analyses of human pythiosis in Thailand. Clin Infect Dis Off Publ Infect Dis Soc Am. 2006;43:569-76.

3. Vanittanakom N, Szekely J, Khanthawong S, Sawutdeechaikul P, Vanittanakom P, Fisher MC. Molecular detection of Pythium insidiosum from soil in Thai agricultural areas. Int $\mathrm{J}$ Med Microbiol. 2014;304:321-6.

4. Supabandhu J, Fisher MC, Mendoza L, Vanittanakom N. Isolation and identification of the human pathogen Pythium insidiosum from environmental samples collected in Thai agricultural areas. Med Mycol. 2008;46:41-52.

5. Presser JW, Goss EM. Environmental sampling reveals that Pythium insidiosum is ubiquitous and genetically diverse in North Central Florida. Med Mycol. 2015;53:674-83.

6. Miller RI. Investigations into the biology of three "phycomycotic" agents pathogenic for horses in Australia. Mycopathologia. 1983;81:23-8.

7. Zambrano CG, Fonseca AOS, Valente JSS, Braga CQ, Sallis ESV, Azevedo MI, et al. Isolation and characterization of Pythium species from swampy areas in the Rio Grande do Sul, Brazil, and evaluation of pathogenicity in an experimental model. Pesqui Veterinária Bras. 2017;37:459-64.

8. Fonseca AO da S, Botton S de A, Nogueira CEW, Corrêa BF, Silveira J de S, de Azevedo MI, et al. In vitro reproduction of the life cycle of Pythium insidiosum from kunkers' equine and their role in the epidemiology of pythiosis. Mycopathologia. 2014;177:123-7.

9. Mendoza L, Hernandez F, Ajello L. Life cycle of the human and animal oomycete pathogen Pythium insidiosum. J Clin Microbiol. 1993;31:2967-73.

10. Chitasombat MN, Jongkhajornpong P, Lekhanont $\mathrm{K}$, Krajaejun T. Recent update in diagnosis and treatment of human pythiosis. PeerJ. 2020;8:e8555.

11. Jaturapaktrarak C, Payattikul P, Lohnoo T, Kumsang Y, Laikul A, Pathomsakulwong W, et al. Protein A/G-based enzyme-linked immunosorbent assay for detection of anti-Pythium insidiosum antibodies in human and animal subjects. BMC Res Notes. 2020;13:135.

12. Intaramat A, Sornprachum T, Chantrathonkul B, Chaisuriya P, Lohnoo T, Yingyong W, et al. Protein A/G-based immunochromatographic test for serodiagnosis of pythiosis in human and animal subjects from Asia and Americas. Med Mycol. 2016;54:641-7.

13. Permpalung N, Worasilchai N, Manothummetha K, Torvorapanit P, Ratanawongphaibul K, Chuleerarux $\mathrm{N}$, et al. Clinical outcomes in ocular pythiosis patients treated with a combination therapy protocol in Thailand: A prospective study. Med Mycol. 2019;57:923-8. 
14. Hasika R, Lalitha P, Radhakrishnan N, Rameshkumar G, Prajna NV, Srinivasan M. Pythium keratitis in South India: Incidence, clinical profile, management, and treatment recommendation. Indian J Ophthalmol. 2019;67:42-7.

15. Agarwal S, lyer G, Srinivasan B, Benurwar S, Agarwal M, Narayanan N, et al. Clinical profile, risk factors and outcome of medical, surgical and adjunct interventions in patients with Pythiuminsidiosum keratitis. Br J Ophthalmol. 2019;103:296-300.

16. Chitasombat MN, Larbcharoensub N, Chindamporn A, Krajaejun T. Clinicopathological features and outcomes of pythiosis. Int J Infect Dis IJID Off Publ Int Soc Infect Dis. 2018;71:33-41.

17. Chitasombat MN, Petchkum P, Horsirimanont S, Sornmayura P, Chindamporn A, Krajaejun T. Vascular pythiosis of carotid artery with meningitis and cerebral septic emboli: A case report and literature review. Med Mycol Case Rep. 2018;21:57-62.

18. Bagga B, Sharma S, Madhuri Guda SJ, Nagpal R, Joseph J, Manjulatha K, et al. Leap forward in the treatment of Pythium insidiosum keratitis. Br J Ophthalmol. 2018;102:1629-33.

19. Agarwal S, lyer G, Srinivasan B, Agarwal M, Panchalam Sampath Kumar S, Therese LK. Clinical profile of pythium keratitis: perioperative measures to reduce risk of recurrence. Br J Ophthalmol. 2017.

20. Lohnoo T, Yingyong W, Kumsang Y, Payattikul P, Jaturapaktrarak C, Chailurkit L-O, et al. Seroprevalence of anti-Pythium insidiosum antibodies in the Thai population. Med Mycol. 2019;57:284-90.

21. Mendoza L, Ajello L, McGinnis MR. Infection caused by the Oomycetous pathogen Pythium insidiosum. J Mycol Med. 1996;6:151-64.

22. Tonpitak W, Pathomsakulwong W, Sornklien C, Krajaejun T, Wutthiwithayaphong S. First confirmed case of nasal pythiosis in a horse in Thailand. JMM Case Rep. 2018;5:e005136.

23. Chindamporn A, Kammarnjessadakul P, Kesdangsakonwut S, Banlunara W. A case of canine cutaneous pythiosis in Thailand. Access Microbiol. 2020.

24. Chareonsirisuthigul T, Khositnithikul R, Intaramat A, Inkomlue R, Sriwanichrak K, Piromsontikorn S, et al. Performance comparison of immunodiffusion, enzyme-linked immunosorbent assay, immunochromatography and hemagglutination for serodiagnosis of human pythiosis. Diagn Microbiol Infect Dis. 2013;76:42-5.

25. Weiblen C, Machado G, Jesus FPK de, Santurio JM, Zanette RA, Pereira DSB, et al. Seroprevalence of Pythium insidiosum infection in equine in Rio Grande do Sul, Brazil. Ciênc Rural. 2016;46:126-31.

26. Argimón S, Abudahab K, Goater RJE, Fedosejev A, Bhai J, Glasner C, et al. Microreact: visualizing and sharing data for genomic epidemiology and phylogeography. Microb Genomics. 2016;2:e000093.

27. Machado G, Weiblen C, Escobar LE. Potential distribution of Pythium insidiosum in Rio Grande do Sul, Brazil, and projections to neighbour countries. Transbound Emerg Dis. 2018;65:1671-9.

28. Tonpitak W, Pathomsakulwong W, Sornklien C, Krajaejun T, Wutthiwithayaphong S. First confirmed case of nasal pythiosis in a horse in Thailand. JMM Case Rep. 2018;5:e005136. 
29. Martins TB, Kommers GD, Trost ME, Inkelmann MA, Fighera RA, Schild AL. A comparative study of the histopathology and immunohistochemistry of pythiosis in horses, dogs and cattle. J Comp Pathol. 2012;146:122-31.

30. Souto EPF, Maia LA, Olinda RG, Galiza GJN, Kommers GD, Miranda-Neto EG, et al. Pythiosis in the Nasal Cavity of Horses. J Comp Pathol. 2016;155:126-9.

31. Dória RG, Carvalho MB, Freitas SH, Laskoski LM, Colodel EM, Mendonça FS, et al. Evaluation of intravenous regional perfusion with amphotericin $B$ and dimethylsulfoxide to treat horses for pythiosis of a limb. BMC Vet Res. 2015;11:152.

32. Dória RGS, Freitas SH, Linardi RL, Mendonça F de S, Arruda LP, Boabaid FM, et al. Treatment of pythiosis in equine limbs using intravenous regional perfusion of amphotericin B. Vet Surg VS. 2012;41:759-65.

33. Reis JL, de Carvalho ECQ, Nogueira RHG, Lemos LS, Mendoza L. Disseminated pythiosis in three horses. Vet Microbiol. 2003;96:289-95.

34. Meireles MC, Riet-Correa F, Fischman O, Zambrano AF, Zambrano MS, Ribeiro GA. Cutaneous pythiosis in horses from Brazil. Mycoses. 1993;36:139-42.

35. Elkhenany $\mathrm{H}$, Nabil S, Abu-Ahmed $\mathrm{H}$, Mahmoud $\mathrm{H}$, Korritum A, Khalifa H. TREATMENT AND OUTCOME OF HORSES WITH CUTANEOUS PYTHIOSIS, AND META-ANALYSIS OF SIMILAR REPORTS. Slov Vet Res. 2019;56. doi:10.26873/SVR-767-2019.

36. dos Santos CEP, Ubiali DG, Pescador CA, Zanette RA, Santurio JM, Marques LC. Epidemiological Survey of Equine Pythiosis in the Brazilian Pantanal and Nearby Areas: Results of 76 Cases. J Equine Vet Sci. 2014;34:270-4.

37. Permpalung N, Worasilchai N, Plongla R, Upala S, Sanguankeo A, Paitoonpong L, et al. Treatment outcomes of surgery, antifungal therapy and immunotherapy in ocular and vascular human pythiosis: a retrospective study of 18 patients. J Antimicrob Chemother. 2015;70:1885-92.

38. Reanpang T, Orrapin S, Orrapin S, Arworn S, Kattipatanapong T, Srisuwan T, et al. Vascular Pythiosis of the Lower Extremity in Northern Thailand: Ten Years' Experience. Int J Low Extrem Wounds. 2015;14:245-50.

39. Bosco $S$ de MG, Bagagli E, Araújo JP, Candeias JMG, de Franco MF, Alencar Marques ME, et al. Human pythiosis, Brazil. Emerg Infect Dis. 2005;11:715-8.

40. Sathapatayavongs B, Leelachaikul P, Prachaktam R, Atichartakarn V, Sriphojanart S, Trairatvorakul P, et al. Human pythiosis associated with thalassemia hemoglobinopathy syndrome. J Infect Dis. 1989;159:274-80.

41. Chaiprasert A, Krajaejun T, Pannanusorn S, Prariyachatigul C, Wanachiwanawin W, Sathapatayavongs $B$, et al. Pythium insidiosum Thai isolates: molecular phylogenetic analysis. Asian Biomed. 2009;3:623-33.

42. Ribeiro TC, Weiblen C, de Azevedo MI, de Avila Botton S, Robe LJ, Pereira DIB, et al. Microevolutionary analyses of Pythium insidiosum isolates of Brazil and Thailand based on exo-1,3- $\beta$-glucanase gene. Infect Genet Evol. 2017;48:58-63. 


\section{Table}

Table 1. Geographic locations, number of recruited horses, and serological test results of 150 equine serum samples.

\begin{tabular}{|c|c|c|c|c|c|c|c|c|}
\hline \multirow{2}{*}{$\begin{array}{l}\text { Region of } \\
\text { Thailand }\end{array}$} & \multirow{2}{*}{$\begin{array}{c}\text { Province } \\
\text { (reference } \\
\text { code) }\end{array}$} & \multicolumn{2}{|c|}{ GPS coordination $^{a}$} & \multirow{2}{*}{$\begin{array}{l}\text { Tested } \\
\text { horses }\end{array}$} & \multirow{2}{*}{$\begin{array}{l}\text { Horse } \\
\text { farms }\end{array}$} & \multicolumn{3}{|c|}{ Positive test results } \\
\hline & & Latitude & Longitude & & & ELISA $^{\mathrm{b}}$ & ICT $^{\mathrm{c}}$ & $\mathrm{WB}^{\mathrm{d}}$ \\
\hline \multirow[t]{2}{*}{ Northern } & Chiang Rai (A) & 19.9105 & 99.8406 & 29 & 2 & - & - & - \\
\hline & Payao (B) & 19.2154 & 100.2024 & 14 & 2 & - & - & - \\
\hline \multirow[t]{3}{*}{ Central } & Suphanburi (C) & 14.4745 & 100.1177 & 10 & 6 & 1 & - & - \\
\hline & $\begin{array}{l}\text { Kanchanaburi } \\
\text { (D) }\end{array}$ & 14.1011 & 99.4179 & 38 & 5 & 1 & - & - \\
\hline & Ratchaburi (E) & 13.5283 & 99.8134 & 38 & 9 & - & - & - \\
\hline \multirow[t]{2}{*}{ Eastern } & $\begin{array}{l}\text { Chachoengsao } \\
\text { (F) }\end{array}$ & 13.6904 & 101.0780 & 8 & 1 & - & - & - \\
\hline & Chonburi (G) & 13.3611 & 100.9847 & 6 & 1 & - & - & - \\
\hline Southern & Trang (H) & 7.5645 & 99.6239 & 7 & 1 & 1 & 1 & 1 \\
\hline \multicolumn{4}{|c|}{ Total } & 150 & 27 & 3 & 1 & 1 \\
\hline
\end{tabular}

\section{Footnote:}

${ }^{a}$ Global Positioning System coordination of the provinces where the horse sera were obtained

b Protein A/G-based enzyme linked immunosorbent assay

c Protein A/G-based immunochromatographic test

d Western blot analysis

Figures 


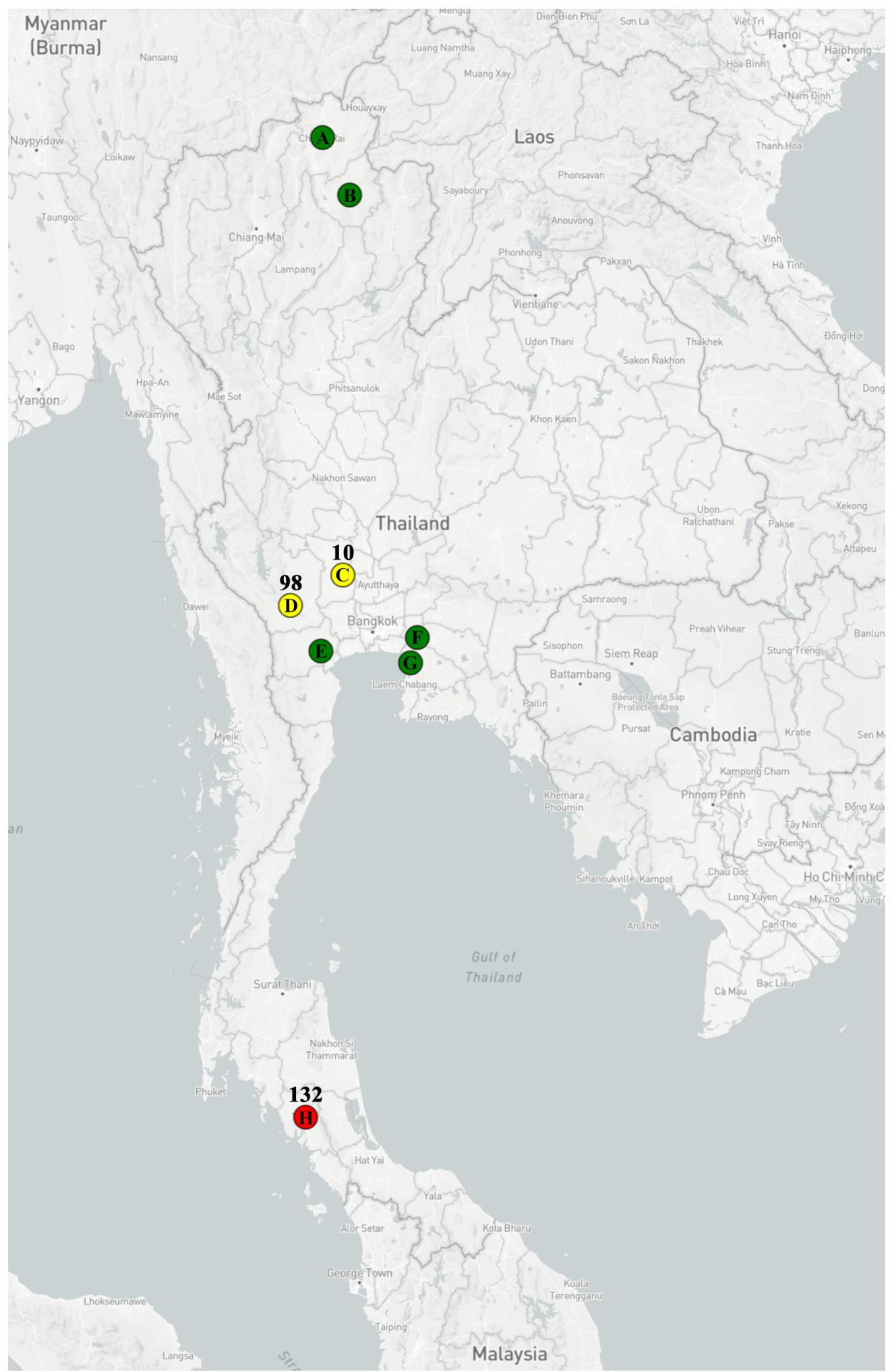

\section{Figure 1}

The map indicates the geographic locations of 8 provinces in the Northern [Chiang Rai (A) and Payao (B)], Central [Suphanburi (C), Kanchanaburi (D) and Ratchaburi (E)], Eastern [Chachoengsao (F) and Chonburi (G)], and Southern [Trang $(H)$ ] regions of Thailand, where the serum samples of 150 horses were obtained. The map was created by the Microreact program (the online version: https://microreact.org/project/f2QcmQktR). A green dot represents the province with ELISA-negative sera. 
A yellow dot shows the province with a seropositive sample by only ELISA. A red dot reveals the province with a seropositive sample by all 3 serological tests (ELISA, ICT, and Western blot). The numbers (\#10, 98, and 132) indicate IDs of the seropositive samples. (Abbreviations: ELISA, enzyme-linked immunosorbent assay; ICT, immunochromatographic test)
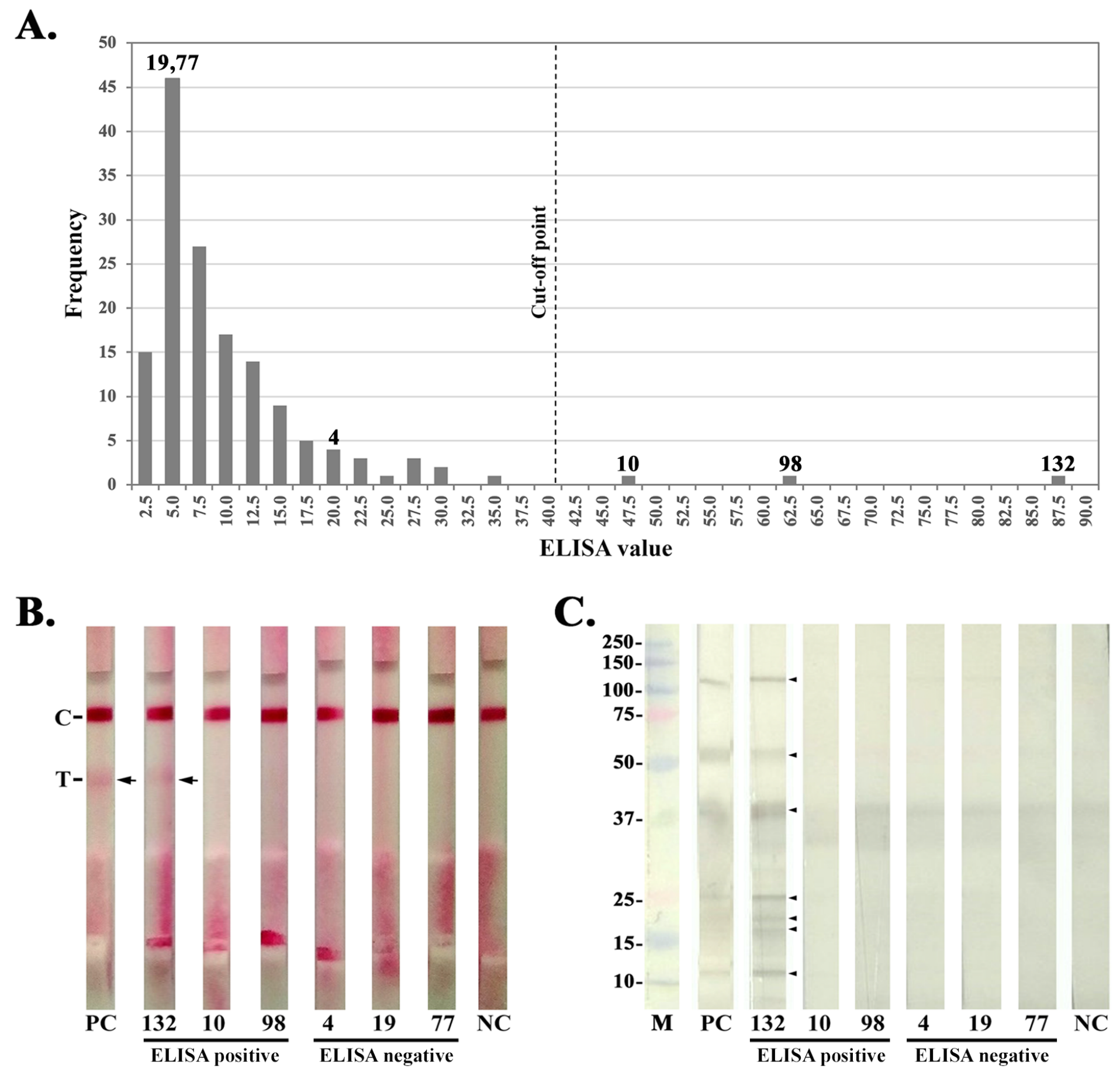

\section{Figure 2}

Serological test results of the serum samples from 150 horses in Thailand: (A) Histogram shows the distribution of ELISA values of all samples according to frequencies and ranges (i.e., 0.0-2.5, 2.6-5.0, 5.1$7.5,7.6-10.0, \ldots)$. The cut-off point is derived from the mean ELISA value plus 3 standard deviations of all 
samples. The numbers represent ELISA-positive samples (IDs 10, 98, and 132) and randomly-selected ELISA-negative samples (IDs 4, 19, and 77) for ICT and Western blot analysis. (B) ICT results of the ELISA-positive and ELISA-negative samples. Arrows indicate the test line (T). $\mathrm{C}$ is the control line. (C) Western blot analysis of the ELISA-positive and ELISA-negative samples. M represents the molecular weight markers $(\mathrm{kDa})$. Arrowheads indicate major immunoreactive bands. (Abbreviations: ELISA, enzymelinked immunosorbent assay; ICT, immunochromatographic test; PC, positive control serum; NC, negative control serum) 